\title{
EFEKTIVITAS MEDIA YOUTUBE DALAM MELESTARIKAN PERMAINAN TRADISIONAL DI LSM BENING SAGULING FOUNDATION DESA CIHAMPELAS
}

\author{
Tugino \\ IKIP Siliwangi, Cimahi, Jawa Barat, Indonesia \\ tugino092@gmail.com
}

Received: Desember 2019 ; Accepted: Januari 2020

\begin{abstract}
this research is based on background. The number of local wisdom that is almost extinct for example traditional games that have a good impact on the growth of children. As we see now, many children do not know the traditional game but know more about online games or what is on each gaget. This study aims to determine the process of managing YouTube's media, in preserving traditional games. The theory used in this study is the concept of PLS, Youtube, traditional games. The researcher formulated three questions related to the title raised, how the responses of the children in LSM Saguling Foundation. yotube media management in LSM saguling foundation In this study researchers used descriptive methods and used a qualitative approach. Data collected through interviews, observation and documentation. As for the population of this study were children who were housed in the clear LSM Saguling Foundation. The results of this study children are less aware of traditional games and LSMplay an active role in preserving traditional games
\end{abstract}

Keywords: youtube, traditional game, non-formal education.

\begin{abstract}
ABSTRAK
penelitian ini dilandasi oleh latar belakang, Banyaknya kearifan lokal yang hampir punah contohnya permainan tradisional yang memiliki dampak baik bagi pertumbuhan anak-anak. Seperti yang diketahui sekarang banyak anak-anak yang tidak tahu dengan permaina tradisional melainkan lebih mengetahui tentang permainan onlen atau yang ada di gaget masing masing. penelitian ini betujuan untuk mengetahui proses pengelolaan media youtube,dalam melestarikan permainan tradisional. Teori yang digunakan dalam penelitian ini adalah konsep PLS, Youtube, permainan tradisional. peneliti merumuskan tiga pertanyaan terkait dengan judul yang diangkat, bagaimana respon anak-anak di LSM bening saguling foundation. pengelolaan media yotube di LSM bening saguling foundation Dalam penelitian ini peneliti menggunakan metode deskriftif dan menggunakan pendekatan kualitatif. Data dikumpulkan melalui wawancara, observasi dan dokumentasi. Adapun yang menjadi populasi penelitian ini yatu anak-anak yang bertempat di LSM bening saguling foundation. Hasil dari penelitian ini anak-anak kurang mengetahui tentang permainan tradisional dan pihak LSM berperan aktif dalam melestarikan permainan tradsional.
\end{abstract}

Kata Kunci: youtube, permainan tradisional, pendidikan luar sekolah.

How to Cite: Tugino, T. (2020). Efektivitas Media Youtube Dalam Melestarikan Permainan Tradisional Di LSM Bening Saguling Foundation Desa Cihampelas. Comm-Edu (Community Education Journal) 3 (1), 56-61. 


\section{PENDAHULUAN}

Di zaman yang semakin modern seperti sekarang ini, permasalah yang semakin kompleks terutama di indonesia bukanlah hal yang baru didengar dan sering dilihat. Seperti halnya anak-anak jaman sekarang mereka lebih fokus mengenali permainan di gadget melainkan permainan tradisional yang memiliki dampak baik kepada pertumbuhan anak-anak. Secara umum pengertian literasi informasi adalah kemelekan atau keberakaksaraan yang di artikan kemampuan huruf atau membaca yang digarisbesari yaitu kemelekan masyarakat terhadap informasi yang ada baik dari segi pendidikan, kesehatan, sosial, pemerintahan, sehingga masyarakat kurang mengetahui informasi yang sedang di perbincangkan.

Awal media internet di kenalkan di dunia pada abad ke 21 pada abad ini dimana perubahan sangat begitu pesat seperti dalam teknologi dan informasi. Dengan terjadinya perkembangan informasi dan teknologi dimana semua informasi sangat begitu mudah diakses, maka perubahan masyarakat dari masyarakat tradisional menjadi masyarakat modern. Perubahan ini juga mempengaruhi adat dan budaya yang ada di suatu daerah atau negara terdapat 143.46 juta jiwa yang menggunakan internet. Populasi dunia sebanyak 6,5 miliar pada tahun 2005, pada tahun 2010 sebanyak 6,9 miliar, sedangkan pada tahun 2017 sebanyak 7,4 miliar. Sedangkan penggunan internet di dunia sebanyak $48 \%$ terjadinya peningkatan yang begitu pesat dari awal 16\% menjadi 48\% (APJII, 2019).

Menurut APJII (asosiasi pengguna jasa internet indonesia). Pada tahun 2018 pengguna internet sebanyak 143,24 juta jiwa yang menggunakan jasa internet. Angka ini akan terus berkembang setiap tahunnya, dari tahun 2016 meningkat sebanyak 50\% pengguna jasa internet.

YouTube adalah sebuah situs web video sharing (berbagi video) yang populer dimana para pengguna dapat memuat, menonton, dan berbagi klip video secara gratis. Didirikan pada bulan februari 2005 oleh 3 orang mantan karyawan PayPal, yaitu Chad Hurley, Steve Chen dan Jawed Karim. Umumnya video-video di YouTube adalah video klip film, TV, serta video buatan para penggunanya sendiri (Faiqah, 2016)

\section{LANDASAN TEORI}

\section{Pengertian Pendidikan Nonformal}

Pendidikan nonformal dimana kegiatannya harus terorganisir serta sistematis, kegiatanpendidikan nonformal memiliki kegiatan diluar kegiatan pendidikan formal dan dilakukan secara mandiri yang memiliki bagian penting untuk mencapai tujuan proses belajar bagi warga belajar yang tidak didapatkan dari sekolah formal (Sudjana, 2000).

UUD no 20 tahun 2003 BAB VI bagian kelima Pasal 26 yang menyebutkan bahwa, "Pendidikan nonformal diselenggarakan bagi masyarakat yang membutuhkan layanan pendidikan yang betujuan sebagai pengganti, penambah, dan/atau pelengkap yang tidak di dapatkan dari pendidikan formal dalam rangka menunjang pendidikan sepanjang hayat.

\section{Permainan Tradisional}

Permainan tradisional adalah merupakan salah satu aset atau peninggalan budaya yang mempunyai ciri khas kebudayaan suatu bangsa, pendidikan karakter dapat dibentuk melalui permainan tradisonal sejak usia dini. Seperti yang diketahui selama ini pendidikan karakter kurang mendapat penekanan dalam sistem pendidikan di Indonesia. Pendidikan karakter 
dalam sistem persekolahan hanya berupa teori tanpa adanya refleksi saat melakukan pendidikan. Dampaknya anak-anak tumbuh sebagai manusia yang tidak memiliki karakter, bahkan sopan santun terhadap orang yang dewasa, kurang pertumbuhkan karakter ini akan terus berkembang mengikuti zaman yang semakin moderen. Dimana semua nya dapat diakses melalui gaget merek masing-masing baik itu infromasi, permainan, dan yang lain-lainnya (Andriani, 2012).

Permainan tradisional adalah, Bagian dari kebudayaan dari berbagai gabungan di dunia pada umumnya dan di Indonesia, yang akan disebarkan secara turun-temurun di antara gabungan atau merupakan dari campuran pemikiran rakyat yang bersangkutan. baik dalam bentuk lisan,atau tulisan contoh yang disertai baik berupa gerakan atau isyarat dan alat pembantu lainnya. Dimana yang mencakup dari kebudayaan adalah permainan tradsional, cerita rakyat, bahasa daerah, kepercayaan yang di percayai oleh rakyat, dan yang lain-lainnya (Hidayat, 2013).

\section{Youtube}

YouTube adalah sebuah situs web video sharing (berbagi video) dan bisa dijadikan mengunggah, menonton dan melihat berbagai video dari penggunan lainnya. Youtube memiliki dua penggunan yaitu penggunan yang tidak terdaftar hanya bisa menonton dalam waktu yang terbatas atau di tentukan, sedangkan pennguna yang terdaftra dapat melakukan mengunggah video. Media yotube didirikan oleh tiga yaitu Chad Hurley, Steve Chen dan Jawed Karim. Yang didirikan pada bulan februrai pada tahun 2005 (Faiqah, 2016).

\section{METODE PENELITIAN}

Dalam penelitian ini peneliti menggunakan metode deskriptif dengan pendekatan kualitatif. pendekatan kualitatif adalah suatu "proses atau kegiatan penelitian pemahaman yang berdasarkan pada metodologi yang menyelidiki suatu fenomena sosial dan masalah manusi untuk mendapatan hasil yang akurat" (Darmadi, 2014).

Pada pendekatan ini peneliti mengambarakn suatu kompleks, meniliti kata-kata,membuat laporan dari hasil responden, dan melakukan studi kasus secara ilmiah dan alami. penelitian kualitatif biasanya bdari hal paling mendasar atau pada latar alamiah sebagai keutuhan, biasanya teknik ini menjadikan manusia sebagai alat penelitian, manfaatkan metode kualitatif dan mengadakan analisis data secara induktif. Penelitian kualitatif lebih mementingkan proses daripada hasil . "Menghendaki adanya batas penelitian atas dasar fokus yang timbul sebagi masalah, memiliki seperangkat kriteria untuk mengukur kesahan atau akurat data melalui kesepakatan antara peneliti dengan subyek yang diteliti” (Moleong, 1990)

Teknik yang digunakan dalam mengumpulakan data adalah wawancara, observasi, dokumentasi, catatan lapangan, dan dokumen resmi lainnya. Alasan dari penelti menggunakan teknik wawancara dan yang lainnya, wawacara adalah suatu teknik untuk menggumpulkan data terkait dari pembahasan yang dijadikan penelitian biasanya wawncara akan mendapatkan data yang akurat dari masyarakat yang diwawancarai. Penelitian ini dilakukan di LSM Bening Saguling Foundation J1.SDN Cianjur, Babakan, Cihampelas, Kec. Cihampelas, Kabupaten Bandung Barat, Jawa Barat. Populasi yang digunakan dalam penelitian baik berupa subjek/objek yang akan di teliti dan dipelajari oleh peneliti. Yang dijadikan populasi dalam penelitian ini adalah anak-anak, pengelola LSM, masyarakat setempat/orang tua warga belajar LSM Bening Saguling Foundation J1.SDN Cianjur, Babakan, Cihampelas, Kec. Cihampelas, Kabupaten Bandung Barat, Jawa Barat. Sedangkan 
untuk sempel penelti mengambil 3 masyarakat setempat,3 orang tua dari anak-anak, 10 anakanak.

Prosedur penelitian merupakan penjelasan langkah-langkah yang harus ditempuh dalam suatu penelitian. Menurut (Moleong, 2007) Langkah-langkah prosedur penelitian meliputi tiga hal yaitu:

1) Tahap Pra Lapangan Tahap ini merupakan tahap awal yang dilakukan peneliti dengan pertimbangan etika penelitian lapangan melalui tahap pembuatan rancangan usulan penelitian hingga menyiapkan perlengkapan penelitian. Dalam tahap ini peneliti diharapkan mampu memahami latar belakang penelitian dengan persiapan-persiapan diri yang mantap untuk masuk dalam lapangan penelitian. Mengadakan pembuatan proposal penelitian, permohonan surat izin, Pembuatan instrumen yang terdiri pedoman wawancara.

2) Tahap Pekerjaan Lapangan Dalam tahap ini peneliti berusaha mempersiapkan diri untuk menggali dan mengumpulkan data-data untuk dibuat suatu analisis data. Memilih subjek yang akan menjadi narasumber dalam penelitian, mengadakan wawancara kepada pengelola dan pengunjung untuk memperoleh informasi mengenai bagaimana pengelolaan. Dokumentasi juga dilakukan sebagai salah satu bukti sudah terjadinya wawancara kepada pengelola dan pengunjung. Setelah itu mengolah data yang didapat secara objektif dan disusun.

3) Tahap Analisis Data Pada tahap ini dilakukan kegiatan yang berupa mengolah data diperoleh dari narasumber maupun dokumen, kemudian akan disusun kedalam sebuah penelitian. Hasil analisis tersebut dituangkan dalam bentuk laporan sementara sebelum menulis keputusan akhir

\section{HASIL DAN PEMBAHSAN}

\section{Hasil}

Penerapan permainan tradisional di LSM bening saguling foundation anak-anak masih banyak yang belum memahami tentang permainan tradisiona. Pengetahuan anak-anak terhdapa permainan tradisional di Bening Saguling Foundation, Berdasarkan hasil wawancara kepada anak-anak sebagian mengakui kurang tahunya terhadap permainan tradisional tetapi ada beberapa yang mengetahui nya. Sehingga permainan tradisional di Bening Sguling Foundation kurang diminati oleh anak-anak dikarnakan anak-anak lebih fokus ke permainan onlen atau yotube di gagt masing masing. Bagitu pula dengan perkembangan perrmainan modern yang semakin hari bertambah modern mengikuti perkembangan dunia barat. Permainan tradisional seperti halnya lompat tali, petak umpet, gobak sodor, engkle sudah jarang dilakukan oleh anak-anak kota.

Proses memperkenalkan kembali permainan tradisional. selama tiga minggu berturut-turut anak-anak menonton suatu permainan tradisional. selama tiga minggu anak-anak menonton 2 atau 3 permainan tradisional di youtube, dan diminggu ke empat anak-anak diajarkan langsung ke lapangan untuk memperaktekan permainan yang sudah ditonton sebelumnya selama 4 hari berturut turut. Dan di minggu selanjutnya anak-anak akan di wawancara terkait pengetahuan tentang permainan tradisional maupun dengan menggunakan angket untuk mengetahu efektiv atau tidaknya media yotube untuk dijadikan saran melestarikan permainan tradisional. 
Setelah melakukan peneltian maka peneliti dapat menarik hasil dari peneltian. Berdasarkan hasil wawancara dan angket menunjukkan bahwa respon dari anak-anak yang memahami kembali permainan tradisonal dan anak-anak lebih memilih permainan tradisional, pengelola LSM sudah mempasilitasi untuk permaian tradisional dan memahami kembali manfaat dari permainan tradisional untuk tumbuh kembang anak-anak dan tugas LSM sangat berperan penting dalam melestarikan kembali permainan tradisional, peran orang tua sangat dibutuhkan untuk memperkenalkan kembali permaina tradisional bisa membantu dengan membatasi penggunaan gaget dan masyarakat setempat bisa mengajarkan atau memperkenalkan kembali prmainan tradisional.

\section{Pembahasan}

Penerapan permainan tradisional di LSM bening saguling foundation anak-anak masih banyak yang belum memahami tentang permainan tradisional. Pengetahuan anak-anak terhdapa permainan tradisional di Bening Saguling Foundation. Berdasarkan hasil wawancara kepada anak-anak sebagian mengakui kurang tahunya terhadap permainan tradisional. Tetapi ada beberapa yang mengetahui nya. Peran orang tua di LSM Bening Saguling Foundation sangat kurang untuk memperkenalkan permainan tradisional, anak-anak memilih memainkan games onlen di gaget mereka masing masing dikarnakan orang tua mempasilitasi gaget yang begitu canggi dan tidak ada pembatasan aak-anak untuk penggunaannya, sedangkan permainan onlen memiliki dampak negatif terhadap pertumbuhan anak-anak. Bagitu pula dengan perkembangan perrmainan modern yang semakin hari bertambah modern mengikuti perkembangan dunia barat. Permainan tradisional seperti halnya lompat tali, petak umpet, gobak sodor, engkle sudah jarang dilakukan oleh anak-anak kota, Mereka lebih mengenal game online, ipod, playstation bahkan mereka mahir dalam memainkan. Terlebih lagi perkembangan internet yang semakin berkembang.

Seperti yang diketahui beberapa permainan tradisinal dalam permainannya membutuhkan kekompakan atau kerjasama contohnya, Dalam gobak sodor, engkle dan juga lompat tali kerjasama sangat dibutuhkan dalam permainan yang dilakukan secara berkelompok ini. dalam permainan ini kerjasama akan mampu membentuk anak-anak jauh lebih aktif dalam kehidupan sosialnya di waktu mendatang. Permainan yang berkelompok seperti permainan benteg-bentengan dan gobak sodor akan melatih sikap sportif karena permainan ini tidak akan bisa dilakukan dengan baik jika mereka bersifat curang karena adanya sanksi dari teman-teman sepermainannyaProses memperkenalkan kembali permainan tradisional. selama tiga minggu berturut-turut anak-anak menonton suatu permainan tradisional menggunak media youtube yang sudah disediakan oleh peneliti, dan setelah menonton selanjutnya anakanak dan peneliti turun kelapangan untuk memperaktekan permaina yang mereka tonton dan partisipan cukup baik dan memahami tentang permainan tradisional dan bisa mengikuti kegiatan.

Pengertian permainan tradisional adalah bagian dari kebudayaan yang berasal dari berbagai gabungan kebiasaan dan adat di dunia dan di Indonesia yang disebarkan turun-temurun di antara kelompok sosial yang bersangkutan, baik dalam bentuk lisan, maupun contoh yang disertai dengan gerak isyarat atau alat pembantu pengingat/ mnemonic. Faktor dapat berupa bahasa rakyat, ungkapan tradisional, teka-teki, cerita rakyat, nyanyian rakyat, permainan rakyat, teater rakyat, kepercayaan rakyat, arsitektur rakyat, musik rakyat, dan sebagainya. Permainan rakyat seringkali juga disebut sebagai permainan tradisional. seperti yang diketahui permainan tradisonal sangat baik dalam kesehatan (Hidayat, 2013). 
Setelah anak-anak diajarkan kembali permainan tradisonal. Berdasarkan hasil wawancara dan angket hasilnya anak-anak memahami kembali permainan tradisonal dan anak-anak memahami kembali permainan tradisional yang sebelumnya tidak pernah dimainkan oleh sebagian anak-anak. pengelola LSM sudah memfasilitasi untuk permaian tradisional dan memahami kembali manfaat dari permainan tradisional untuk tumbuh kembang anak-anak, peran orang tua sangat dibutuhkan untuk memperkenalkan kembali permainan tradisional bisa membantu dengan membatasi penggunaan gaget dan masyarakat setempat bisa mengajarkan atau memperkenalkan kembali prmainan tradisional dan setelah dilihat kembali anak-anak lebih memilih permainan tradisional dan pihak LSM pun menyedikan kembali sarana untuk permainan tradisional, dan dapat dilihat terjadinya kekompakan atau sosial yang terjadi dalam permainan tradisional sehingga anak-anak sedikit mengurangi gawai untuk dijadikan sarana mencari hiburan.

\section{KESIMPULAN}

Dari hasil penelitian dan pembahsan diatas maka peneliti dapat menarik kesimpulan bahwa masih ada anak-anak yang masih peduli dan ada beberapa anak-anak rasa ingin tahu dan memahami kembali tentang permainan tradisional dan ingin kembali memainkan permainan tradisional dan peran LSM sangat di butuhkan dalam melestarikan kembali permainan tradisional baik itu sarana permainan ataupun startegi dalam melestarikan kembali dan peran orang tua sangat dibutuhkan untuk membantu membatasi anak-anak dalam menggunakan gaget untuk permaina onlen yang memiliki dampak negatif bagi tumbuh kembangnya anakanaknya.

\section{DAFTAR PUSTAKA}

Andriani, T. (2012). Permainan Tradisional Dalam Membentuk Karakter Anak Usia Dini. Sosial Budaya, 121-136.

APJII. (2019). Buletin APJII. Jakarta: Asosiasi Penyelenggara Jasa Internet Indonesia.

Darmadi, H. (2014). Metode Penelitian Pendidikan Sosial. Bandung: Alfabeta.

Faiqah, F. (2016). Youtube Sebagai Sarana Komunikasi Bagi. Jurnal Komunikasi KAREBA, 259.

Hidayat, D. (2013). Permainan Tradisional Dan Kearifan Lokal. JURNAL ACADEMICA Fisip Untad, 1057-1070.

Moleong, L. J. (1990). Metodelogi Penelitian Kualitatif. Bandung: Remaja Rosdakarya.

Moleong, L. J. (2007). Metodologi Penelitian Kualitatif Edisi Revisi. Bandung: Remaja Rosdakarya.

Sudjana, D. (2000). Strategi Pembelajaran Dalam Pendidikan Luar Sekolah. Bandung: Nusantara Press. 